\title{
Continuous suture technique in aortic valve replacement
}

\author{
I Panagiotopoulos, I Linardakis, K Katsavrias, D Pavlopoulos, S Prapas \\ From 23rd World Congress of the World Society of Cardio-Thoracic Surgeons \\ Split, Croatia. 12-15 September 2013
}

\section{Background}

The aim of the study is to describe our experience in using continuous suture technique for aortic valve replacement and to evaluate the possible advantages of it.

\section{Methods}

Between February 2001 and October 2011, a total number of 443 patients with aortic valve stenosis underwent aortic valve replacement. It was isolated in 217 patients (group A), combined with coronary vascularisation in 137 cases (group B) and with other concomitant cardiac procedures in 89 cases (group C). In all groups continuous suture technique was used. The most of coronary anastomosis performed "off pump" and only few of them on a beating heart with the support of the pump. Valves used were metallic in 247 cases, stented in bioprostheses in 188 cases and unstented bioprostheses in 8 cases. Sizes of the valves varied from 19 to 27 . The valve had always the size of the annulus except for few cases in which the annulus was greater than 27 .

\section{Results}

The cross-clamp time and bypass time were similar in groups A and B and significantly longer in group C. No perivalvural leak was detected in entry postoperative echocardiograms. There was no need for aortic annulus enlargement. Hospital mortality was $3,5 \%$ in group A, $4,3 \%$ in group $\mathrm{B}$ and $3,3 \%$ in group $\mathrm{C}$, respectively. There were no deaths or complications associated with suture technique. During the follow-up period 2 patients of group A and 1 patient of group C developed perivalvural leakage requiring reoperation. The reason was tearing of the annulus tissue. In all cases the metallic valves placed were smaller in size than the enlarged annulus size.

\footnotetext{
* Correspondence: sprapas@dunanthospi.gr

Cardiac Surgery Dpt., Henry Dunant Hospital, Athens, Greece
}

\section{Conclusions}

Continuous suture method is safe and useful for aortic valve replacement technique. It is simple, quick and effective, saving bypass and cross clamp time in benefit of other cardiac procedures. Combined with off pump coronary revascularisation, it reduces the danger of the operation. However, in cases with large aortic annulus it must be avoided.

Published: 11 September 2013

doi:10.1186/1749-8090-8-S1-031

Cite this article as: Panagiotopoulos et al: Continuous suture technique

in aortic valve replacement. Journal of Cardiothoracic Surgery 20138 (Suppl 1):O31.
Submit your next manuscript to BioMed Central and take full advantage of:

- Convenient online submission

- Thorough peer review

- No space constraints or color figure charges

- Immediate publication on acceptance

- Inclusion in PubMed, CAS, Scopus and Google Scholar

- Research which is freely available for redistribution
() Bïomed Central
C Biomed Central

(c) 2013 Panagiotopoulos et al; licensee BioMed Central Ltd. This is an Open Access article distributed under the terms of the Creative Commons Attribution License (http://creativecommons.org/licenses/by/2.0), which permits unrestricted use, distribution, and reproduction in any medium, provided the original work is properly cited. 